\title{
Inhibitory effect of Korean Red Ginseng on melanocyte proliferation and its possible implication in GM-CSF mediated signaling
}

\author{
Chang Taek $\mathrm{Oh}^{1}$, Jong Il Park ${ }^{1}$, Yi Ra Jung ${ }^{1}$, Yeon Ah Joo ${ }^{1}$, Dong Ha Shin ${ }^{1}$, Hyoung Joo Cho ${ }^{1}$, \\ Soo Mi Ahn' ${ }^{2}$ Young-Ho Lim ${ }^{3}$, Chae Kyu Park ${ }^{3}$, and Jae Sung Hwang, ${ }^{1 *}$ \\ ${ }^{1}$ Department of Genetic Engineering, College of Life Science, Kyung Hee University, Yongin 446-701, Korea \\ ${ }^{2}$ Skin Biotechnology Center, Kyung Hee University, Yongin 443-766, Korea \\ ${ }^{3}$ KGC R\&D Headquarters, Daejeon 305-805, Korea
}

Korean Red Ginseng (KRG) has been reported to exert anticancer, anti-oxidant, and anti-inflammatory effects. However, there has been no report on the effect of KRG on skin pigmentation. In this study, we investigated the inhibitory effect of KRG on melanocyte proliferation. KRG extract (KRGE) at different concentrations had no effect on melanin synthesis in melan-A melanocytes. Saponin of KRG (SKRG) inhibited melanin content to 80\% of the control at 100 ppm. Keratinocyte-derived factors induced by UV-irradiation were reported to stimulate melanogenesis, differentiation, proliferation, and dendrite formation. In this study, treatment of melan-A melanocytes with conditioned media from UV-irradiated SP-1 keratinocytes increased melanocyte proliferation. When UV-irradiated SP-1 keratinocytes were treated with KRGE or SKRG, the increase of melanocyte proliferation by the conditioned media was blocked. Granulocyte-macrophage colony-stimulating factor (GM-CSF) was produced and released from UV-irradiated keratinocytes. This factor has been reported to be involved in regulating the proliferation and differentiation of epidermal melanocytes. In this study, GM-CSF was significantly increased in SP-1 keratinocytes by UVB irradiation $\left(30 \mathrm{~mJ} / \mathrm{cm}^{2}\right)$, and the proliferation of melan-A melanocytes increased significantly by GM-CSF treatment. In addition, the proliferative effect of keratinocyte-conditioned media on melan-A melanocytes was blocked by anti-GM-CSF treatment. KRGE or SKRG treatment decreased the expression of GM-CSF in SP-1 keratinocytes induced by UVB irradiation. These results demonstrate that UV irradiation induced GM-CSF expression in keratinocytes and KRGE or SKRG inhibited its expression. Therefore, KRG could be a good candidate for regulating UV-induced melanocyte proliferation.

Keywords: Panax ginseng, Korean Red Ginseng, Ultraviolet radiation, Skin pigmentation, Granulocyte-macrophage colonystimulating factor

\section{INTRODUCTION}

The root of ginseng (Panax ginseng Meyer) has been known as folk medicine in East Asian countries since time immemorial, and is now one of the most largely used herbal drugs in the world [1,2]. Korean Red Ginseng (KRG) is a herb cultivated and aged for 4 to 6 yr or more and requires extensive cleaning, steaming, and drying

cc This is an Open Access article distributed under the terms of the Creative Commons Attribution Non-Commercial License (http://creativecommons.org/licenses/by-nc/3.0/) which permits unrestricted non-commercial use, distribution, and reproduction in any medium, provided the original work is properly cited. processes before use [3]. In Korea, KRG is widely used, and frequently as a health supplement in food including beverages, candy, jellies, and snacks $[4,5]$. The active components in ginseng include ginsenosides, polysaccharides, peptides, polyacetylenic alcohols, vitamins, minor elements, and enzymes [6,7]. KRG has been shown to

Edited by Hyeyoung Min, Chung-Ang University, Korea

Received 02 Mar. 2013, Revised 13 Apr. 2013, Accepted 15 Apr. 2013

*Corresponding author

E-mail: jshwang@khu.ac.kr

Tel: +82-31-888-6179, Fax: +82-31-888-6173 
have several pharmacological functions, such as memory enhancing activities [8], antihypertensive [9], antitumor [10], antistress [11], antidiabetic [12], potentiation of erectile response [13], and aphrodisiac [14] functions. Previous studies of KRG's effects on skin were related to atopic dermatitis [15] and anti-aging [16], anti-oxidant [17], and anti-inflammatory [18] activities. However, the effects of KRG on skin pigmentation have not been investigated.

Hyperpigmentory disorders such as chloasma and freckles are due to abnormally increased epidermal melanin [18-21]. Some of the principle causes of hyperpigmentation are exposure to UV radiation, genetic factors, metabolism, inflammation, infection, the endocrine system, and scars [22,23]. Hyperpigmentation generally results from three major steps in the epidermis: proliferation of melanocytes, synthesis and activation of tyrosinase to produce melanin, and transfer of melanosomes to keratinocytes [24,25]. Numerous studies have reported on hyperpigmentation induced by UV radiation [26,27]. UV radiation is the most powerful and well-known extrinsic factor that enhances skin pigmentation [28]. Thus, UV radiation has many adverse effects on human skin, including cancer, immunosuppression, erythema, hyperpigmentation, and photo-aging [29-33].

UV irradiation increases proliferation, dendritogenesis, and melanogenesis of mouse and human melanocytes [34-38]. UV radiation that penetrates the epidermis stimulates keratinocytes to produce inflammatory cytokines and factors such as interleukin (IL)-1 [39], IL-10 [40], tumor necrosis factor (TNF)- $\alpha$ [41], basic fibroblast growth factor [42], endothelin-1 [43], $\alpha$-melanocyte-stimulating hormone [44], stem cell factor [45], and granulocyte macrophage colony-stimulating factor (GM-CSF) [46]. A complicated network composed of paracrine and autocrine cytokines secreted by keratinocytes and by melanocytes plays an important role in regulating melanogenesis along with their corresponding receptors [47]. In addition, several types of cross-talk among cytokine receptor signaling pathways are involved in enhanced proliferation and melanogenic activities of melanocytes.

Hyperpigmentation is clinically observed in response to inflammation [48]. Many research groups are investigating the regulation of skin pigmentation with the goal of developing hypopigmention and/or tanning cosmetics and also to elucidate the mechanisms of pigmentary disorders to cure and/or prevent such diseases. In the present study, we examined the inhibitory effect of KRG on UVinduced pigmentation in immortalized mouse keratinocytes (SP-1 cells) and immortalized mouse melanocytes (melan-A cells).

\section{MATERIALS AND METHODS}

\section{Compound and reagents}

Total extract and saponin of KRG were provided by the Korea Ginseng Corporation (Daejeon, Korea). Phenylthiourea (PTU), Kojic acid, and phorbol 12-myristate 13-acetate (PMA) were purchased from Sigma-Aldrich (St, Louis, MO, USA). Fetal bovine serum (FBS) and RPMI 1640 media were purchased from WelGENE (Daegu, Korea). Newborn calf serum (NBCS) was purchased from Gibco Invitrogen (Carlsbad, CA, USA). GM-CSF, anti-GM-CSF, and r-IgG were purchased from Abcam (Cambridge, UK).

\section{Cell culture}

Murine melan-A melanocytes were kindly gifted from Prof. Dorothy C. Bennett (St. George’s Hospital, London, UK) [49]. Melan-A cells were maintained in RPMI1640 (WelGENE) medium supplemented with 10\% FBS, $1 \%$ penicillin/streptomycin (P/S), and $200 \mathrm{nM}$ PMA.

Murine SP-1 keratinocytes were derived from Sencar mice and were generously provided by Dr. Stuart H. Yuspa (Laboratory of Cellular Carcinogenesis and Tumor Promotion, NCI, NIH). SP-1 keratinocytes were grown in Eagle’s Minimum Essential Medium (EMEM) containing $0.05 \mathrm{mM} \mathrm{Ca}^{2+}$, 8\% Chelex-treated heat-inactivated $\mathrm{NBCS}$, and $1 \% \mathrm{P} / \mathrm{S}[50]$. Under these conditions, the doubling time for melanocytes and keratinocytes was about two and three days, respectively.

\section{Cell viability assay}

Melan-A melanocytes were seeded in 96 well plates $\left(2 \times 10^{4}\right.$ cells/well). After $24 \mathrm{~h}$ at $37^{\circ} \mathrm{C}$, the medium was replaced with media containing total extract and saponin of KRG (SKRG) diluted to the appropriate concentrations. Control cells were treated with dimethyl sulfoxide (DMSO) at a final concentration of $0.1 \%$. After $24 \mathrm{~h}$, the media containing the compounds or DMSO was replaced with media containing 10\% EZ-CyTox (Daeil Lab Service, Seoul, Korea). The cells were then incubated at $37^{\circ} \mathrm{C}$ for $30 \mathrm{~min}$, and the absorbance was measured using a microplate reader (Tecan, Mannedorf, Switzerland) at a wavelength of $450 \mathrm{~nm}$. All assays were performed in triplicate. The cytotoxic effect of each treatment was expressed as a percentage of cell viability relative to the untreated control cells.

\section{Melanin assay}

Melan-A melanocytes were seeded in 24 well plates $\left(1 \times 10^{5}\right.$ cells/well $)$ in RPMI 1640 medium containing 
$10 \% \mathrm{FBS}, 1 \% \mathrm{P} / \mathrm{S}$, and $200 \mathrm{nM}$ PMA for $72 \mathrm{~h}$. After washing with Dulbecco's phosphate buffered saline (DPBS), the cells were dissolved in $100 \mu \mathrm{L}$ of $1 \mathrm{~N} \mathrm{NaOH}$ at $60^{\circ} \mathrm{C}$ for $30 \mathrm{~min}$. Then, the lysates were measured at $470 \mathrm{~nm}$ using a microplate reader. The data were normalized to the protein content of the cell lysates. The cell lysates were subsequently processed for determination of the protein concentration using a BCA Protein Assay kit (Pierce Biotechnology, Rockford, IL, USA).

\section{Tyrosinase activity assay (extracted from melan-A melanocytes)}

Melan-A melanocytes were seeded in 100-mm culture dishes $\left(1 \times 10^{7}\right.$ cells/ dish) and cultured for $24 \mathrm{~h}$. The cells were removed from culture dishes and lysed in tyrosinase extract buffer and assayed for tyrosinase activity. KRG extract (KRGE) was diluted with an equal volume of 0.5 $\mathrm{M}$ potassium phosphate buffer ( $\mathrm{pH}$ 6.8) and cell tyrosinase extracts were placed in the wells of 96 well plates. Then, the enzymatic assay was started by adding L-3, 4-dihydroxyphenylalanine $(2 \mathrm{mg} / \mathrm{mL})$ solution for 60 min. Instead of a sample, DMSO was added as a blank solution. The value of each measurement was expressed as the percent change from the control and normalized by the protein content. The cell extracts were subsequently processed for determination of the protein concentration using a BCA Protein Assay kit (Pierce Biotechnology).

\section{Cell proliferation assay}

SP-1 keratinocytes were seeded in 60-mm culture dishes $\left(1.5 \times 10^{6}\right.$ cells/dish). After $24 \mathrm{~h}, \mathrm{SP}-1$ keratinocytes were washed with DPBS and replenished with serumfree EMEM. After starvation for $24 \mathrm{~h}, \mathrm{SP}-1$ keratinocytes were washed with DPBS and exposed to UV radiation by a UV irradiation system (Vilber Lourmat, Marne la Vallee, France). After irradiation, the cells were replaced with 2\% NBCS EMEM. After $24 \mathrm{~h}$, the conditioned media was used to treat melan-A melanocytes seeded in 24 well plates $\left(1 \times 10^{4}\right.$ cells/well) for 24 to $72 \mathrm{~h}$. After 24,48 , and $72 \mathrm{~h}$, the media containing the compounds or DMSO was replaced with media containing 10\% EZ-CyTox (Daeil Lab Service). The cells were then incubated at $37^{\circ} \mathrm{C}$ for $2 \mathrm{~h}$, and the absorbance was measured using a microplate reader at a wavelength of $450 \mathrm{~nm}$. All assays were performed in triplicate. The proliferation effect of each treatment was expressed as a percentage of cell viability relative to the non-irradiated control cells.

\section{Enzyme-linked immunosorbent assay}

Production of cytokines in SP-1 keratinocyte cells was measured with an enzyme-linked immunosorbent assay (ELISA) kit (eBioscience, San Diego, CA, USA). SP-1 keratinocytes were seeded in 24 well plates $\left(1.5 \times 10^{5}\right.$ cells/well). After $24 \mathrm{~h}$, the cells were washed with DPBS and replenished with serum-free EMEM containing total extract and SKRG. After starvation for 24 h, SP-1 keratinocytes were washed with DPBS and exposed to a radiation dose of $30 \mathrm{~mJ} / \mathrm{cm}^{2}$ of UVB (290-320 nm) light by a UV irradiation system. After irradiation, the cells were replaced with 2\% NBCS EMEM containing KRGE. After $24 \mathrm{~h}$, conditioned media from the UV-irradiated SP-1 keratinocytes was collected and stored at $-80^{\circ} \mathrm{C}$ until ELISA was performed for measurement of cytokine production. Immune plates (96 well) were coated with cytokine capture antibody overnight at $4^{\circ} \mathrm{C}$. The cytokine capture antibody was removed, the wells were washed 5 times with washing buffer ( $0.05 \%$ Tween 20 in PBS), and then blocked with $1 \mathrm{X}$ assay diluent for $1 \mathrm{~h}$ at room temperature. The wells were washed 5 times, then $100 \mu \mathrm{L}$ aliquots of standard (recombinant mouse cytokine) and sample were added to each well, and the plates were incubated for $2 \mathrm{~h}$ at room temperature. The plates were washed 5 times with wash buffer, then cytokine detection antibody was added, and incubation was continued for $1 \mathrm{~h}$ at room temperature. The solution in the wells was removed and the wells were washed 5 times with wash buffer. Next, $100 \mu \mathrm{L}$ of avidin-HRP was added to each well, and the plates were incubated for $30 \mathrm{~min}$ at room temperature. The wells were washed 7 times, then $100 \mu \mathrm{L}$ aliquots of 1X TMB substrate solution were added to each well, and the plates were incubated for $15 \mathrm{~min}$ at room temperature. The color reaction was quenched with stop solution (50 $\mu \mathrm{L}, 1 \mathrm{~N} \mathrm{H}_{2} \mathrm{SO}_{4}$ ). The absorbance was measured using a microplate reader at a wavelength of $450 \mathrm{~nm}$.

\section{Neutralization assay}

SP-1 keratinocytes were seeded in 60-mm culture dishes $\left(1.5 \times 10^{6} \mathrm{cells} / \mathrm{dish}\right)$. After $24 \mathrm{~h}$, the cells were washed with DPBS and replenished with serum-free EMEM. After starvation for 24 h, SP-1 keratinocytes were washed with DPBS and exposed to a radiation dose of $30 \mathrm{~mJ} / \mathrm{cm}^{2}$ of UVB (290 to $320 \mathrm{~nm}$ ) light by a UV irradiation system. After irradiation, the cells were replaced with 2\% NBCS EMEM containing r-IgG or antiGM-CSF. After $24 \mathrm{~h}$, the conditioned media was used to treat melan-A melanocytes seeded in 24 well plates $\left(1 \times 10^{4}\right.$ cells/well $)$ for $3 \mathrm{~d}$.

\section{Statistical analysis}

All values in figures are expressed as means \pm SEM. 


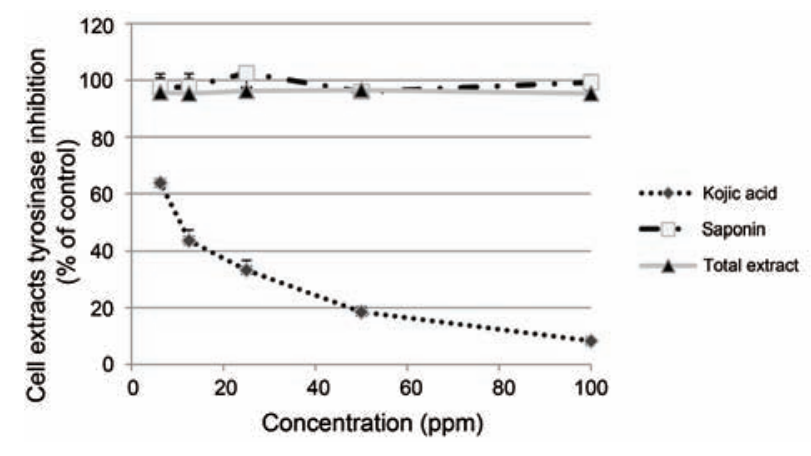

Fig. 1. Effect of Korean Red Ginseng (KRG) on tyrosinase activity. Total extract or saponin of KRG $(100,50,25,12.5,6.25$, and $3.125 \mathrm{ppm}$ ) was incubated with tyrosine cell extracts for $60 \mathrm{~min}$ at $37^{\circ} \mathrm{C}$. Absorbance was measured at $490 \mathrm{~nm}$. Data are shown as average \pm SEM. ${ }^{*} p<0.05$, compared with the control.
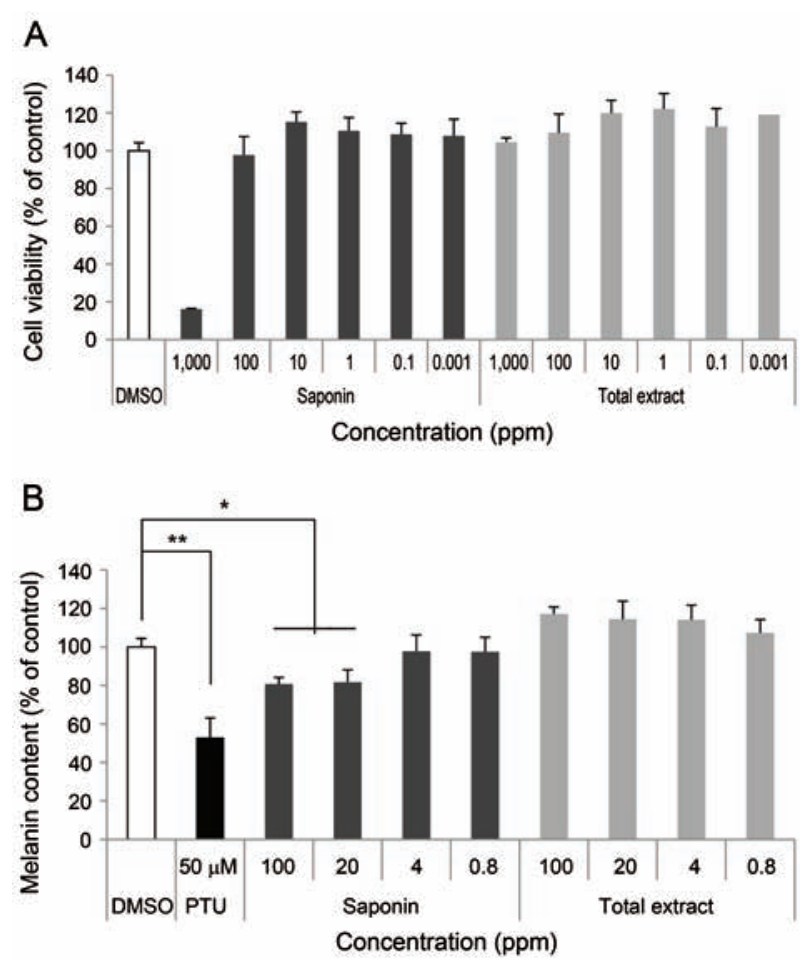

Fig. 2. Effect of Korean Red Ginseng (KRG) on melanin synthesis. (A) Cell viability was measured in melan-A melanocytes. Melan-A melanocytes $\left(2 \times 10^{4}\right.$ cells/well) were cultured in 96 well plates. After incubation with total extract or saponin of KRG (SKRG) for $24 \mathrm{~h}$, cell viability was measured using a water soluble tetrazolium salt-1 assay. (B) Melan-A melanocytes $\left(1 \times 10^{5} \mathrm{cells} /\right.$ well) were cultured in 24 well plates. The melanin content of the cells was measured after incubation with total extract, SKRG $(100,20,4$, and $0.8 \mathrm{ppm})$, or 50 $\mu \mathrm{M}$ phenylthiourea (PTU) for $72 \mathrm{~h}$. Data are shown as average \pm SEM. ${ }^{*} p<0.05,{ }^{*} p<0.01$, compared with the control. DMSO, dimethyl sulfoxide.

The analysis was conducted using one-way ANOVA's (IBM SPSS ver. 20.0; IBM, Armonk, NY, USA) and p-values less than 0.05 were considered statistically significant.
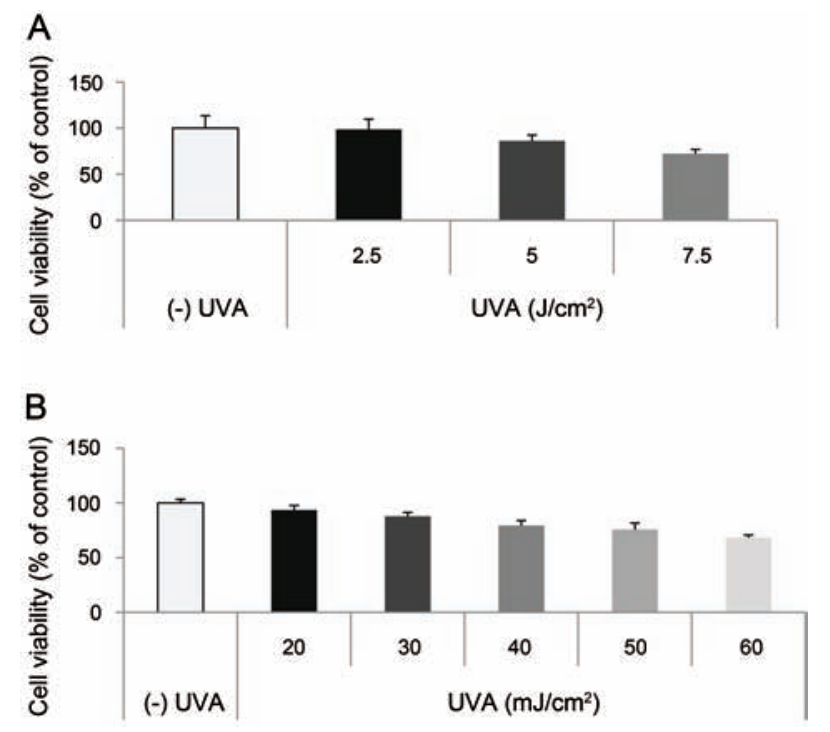

Fig. 3. Effect of UV on SP-1 keratinocyte viability. SP-1 keratinocytes were exposed to UVA at doses ranging from 2.5 to $7.5 \mathrm{~J} / \mathrm{cm}^{2}$ or UVB at doses ranging from 20 to $60 \mathrm{~mJ} / \mathrm{cm}^{2}$. Cell viability was examined at $24 \mathrm{~h}$. SP-1 keratinocyte viability following (A) UVA or (B) UVB irradiation. Data are shown as average \pm SEM.

\section{RESULTS}

\section{Effect of Korean Red Ginseng on tyrosinase activ- ity}

To demonstrate whether KRG inhibits tyrosinase activity directly, tyrosinase activity was measured in cell lysates from melan-A melanocytes. Total lysates and SKRG did not inhibit tyrosinase activity directly in the cell lysates (Fig. 1). Kojic acid, a well known tyrosinase inhibitor was used as a positive control [51].

\section{Effect of Korean Red Ginseng on melanin synthesis}

The cytotoxicity of KRGE on melan-A melanocytes was measured by the water soluble tetrazolium salt- 1 assay. The cells were seeded in 96 well plates at $2 \times 10^{4}$ cells/well and treated with different concentrations of each KRGE (0.001 to 1,000 ppm) for $24 \mathrm{~h}$. SKRG reduced cell viability under $20 \%$ at 1,000 ppm (Fig. 2A).

To further determine whether KRGE regulates melanin synthesis, melanin content was measured after treatment with red ginseng extracts. KRGE did not inhibit melanin content at 0.8 to $100 \mathrm{ppm}$. SKRG inhibited melanin content to $80 \%$ of the control at 100 ppm (Fig. 2B).

\section{Effect of UV on SP-1 keratinocyte viability}

To determine the dosage of UV radiation, we measured cell viability in UV-irradiated SP-1 keratinocytes. UVA irradiation with $7.5 \mathrm{~J} / \mathrm{cm}^{2}$ reduced cell viability by 

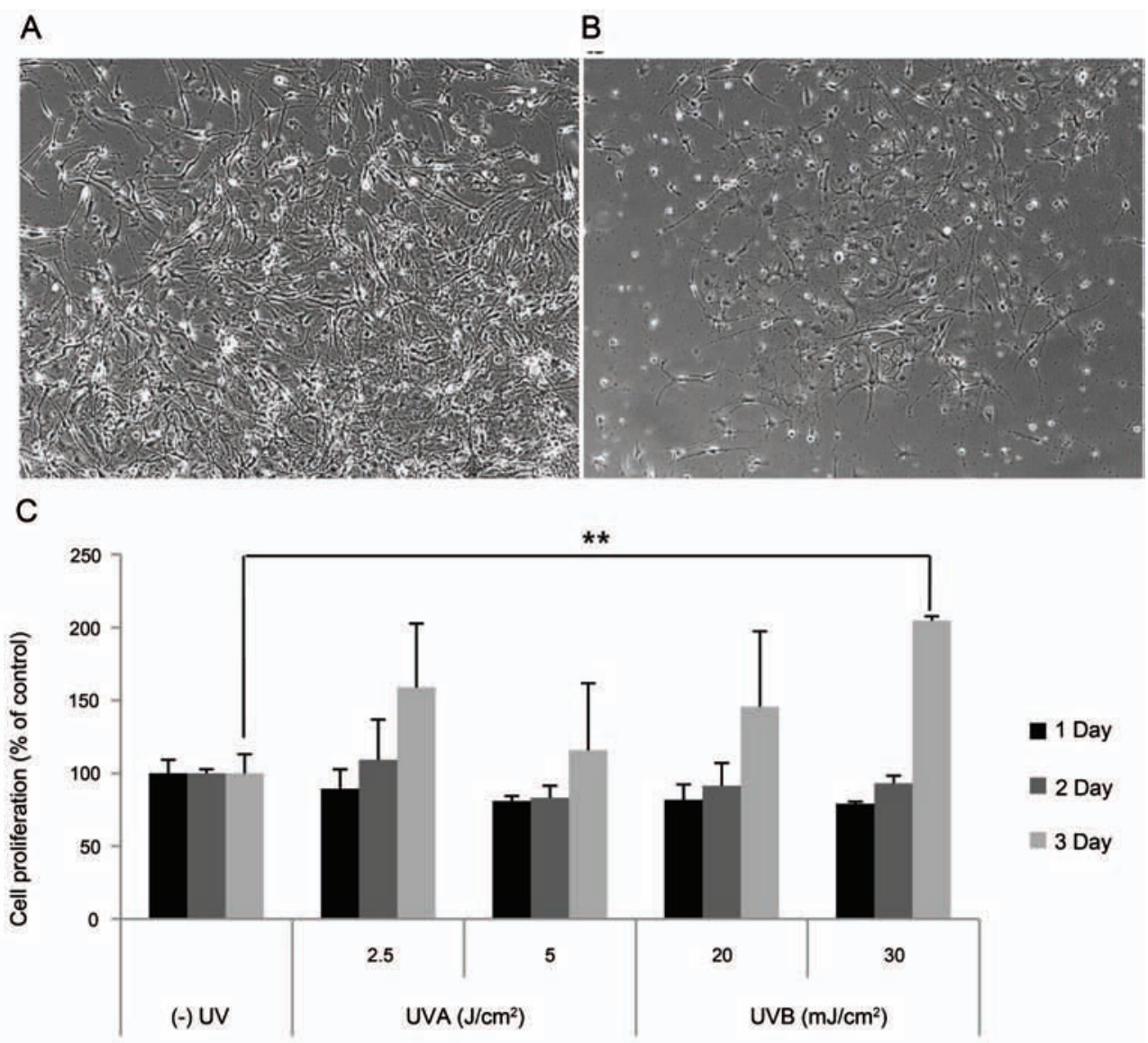

Fig. 4. Effect of conditioned media from UV-irradiated SP-1 keratinocytes on melan-A melanocyte proliferation. SP-1 keratinocytes were exposed to UVA $\left(2.5,5 \mathrm{~J} / \mathrm{cm}^{2}\right)$ or UVB $\left(20,30 \mathrm{~mJ} / \mathrm{cm}^{2}\right)$. After $24 \mathrm{~h}$, the conditioned media was used to treat melan-A melanocytes. After $72 \mathrm{~h}$, melan-A melanocyte proliferation was measured as described in the Materials and Methods. (A) UVB $\left(30 \mathrm{~mJ} / \mathrm{cm}^{2}\right)$ irradiated conditioned media, (B) control, and (C) cell proliferation assay. Cells were observed under a phase-contrast microscope (Olympus CKX41; Olympus Optical, Tokyo, Japan) and images were photographed using a DMCe camera (INS Industry, Seoul, Korea) and the included DMC advanced software $(\times 100)$. Data are shown as average \pm SEM. ${ }^{* *} p<0.01$, compared with the control.

up to $70 \%$ (Fig. 3A). UVB irradiation with $40 \mathrm{~mJ} / \mathrm{cm}^{2}$ reduced cell viability by up to $80 \%$ (Fig. 3B). From these results, we determined the dose of UVA from 2.5 to $5 \mathrm{~J} /$ $\mathrm{cm}^{2}$ and UVB from 20 to $30 \mathrm{~mJ} / \mathrm{cm}^{2}$.

\section{Effect of conditioned media from UV-irradiated SP-1 keratinocytes on melan-A melanocyte prolif- eration}

To elucidate the effect of conditioned media from UVirradiated SP-1 keratinocytes, we irradiated SP-1 keratinocytes with UV radiation. Then, the conditioned media from UVA $\left(2.5,5 \mathrm{~J} / \mathrm{cm}^{2}\right)$ - or UVB $\left(20,30 \mathrm{~mJ} / \mathrm{cm}^{2}\right)$ irradiated SP-1 keratinocytes was used to treat melanA melanocytes. Treatment with conditioned media from UV-irradiated SP-1 keratinocytes increased melan-A melanocyte proliferation. Cell density alterations of melan-A melanocytes exposed to SP-1 keratinocytes conditioned media irradiated with $30 \mathrm{~mJ} / \mathrm{cm}^{2}$ of UVB were viewed by phase-contrast microscopy. The cell density was markedly increased in UVB irradiated SP-1 keratinocyte conditioned media treated melan-A cells (Fig. 4A), compared with the non-irradiated control (Fig. 4B) at 72h. Specifically, conditioned media from SP-1 keratinocytes irradiated with $30 \mathrm{~mJ} / \mathrm{cm}^{2}$ of UVB increased melan-A melanocyte proliferation about two-fold compared with the non-irradiated control (Fig. 4C).

\section{Effect of Korean Red Ginseng on proliferation of melan-A melanocytes induced by conditioned me- dia from UV-irradiated SP-1 keratinocytes}

To elucidate the effect of KRG on proliferation of melan-A melanocytes induced by conditioned media from UVB-irradiated SP-1 keratinocytes, conditioned media from UVB-irradiated SP-1 keratinocytes treated with KRG was tested on melan-A melanocytes. SP-1 keratinocytes were seeded in 60 -mm culture dishes $\left(1.5 \times 10^{6}\right.$ 
A
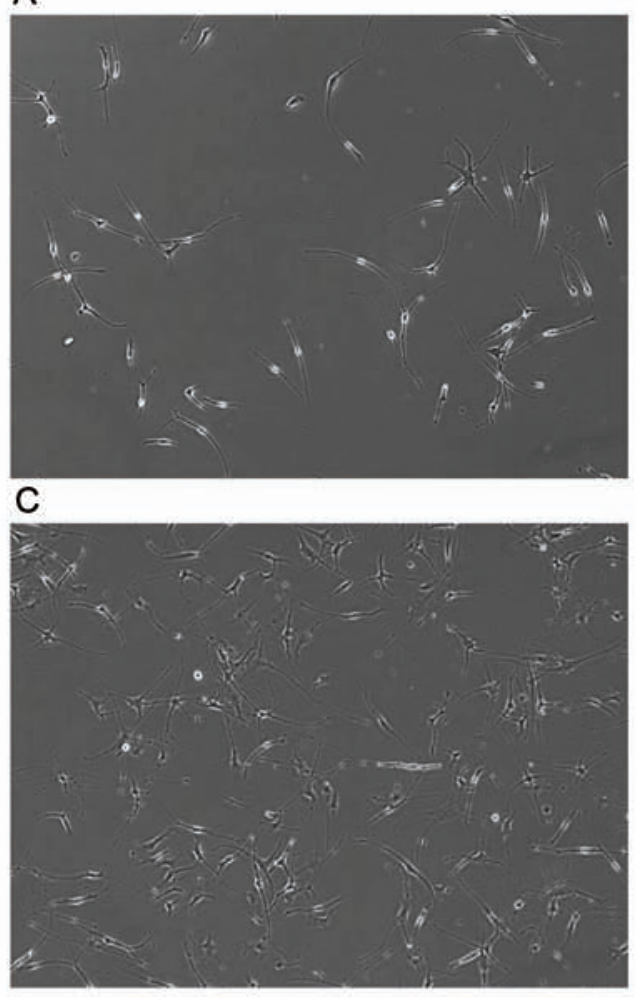

B

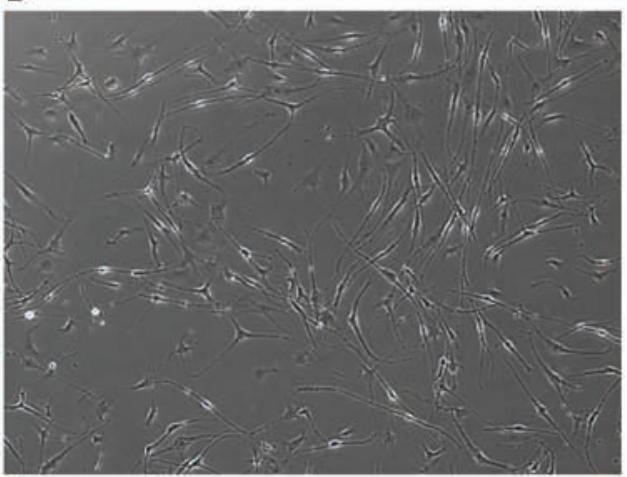

D

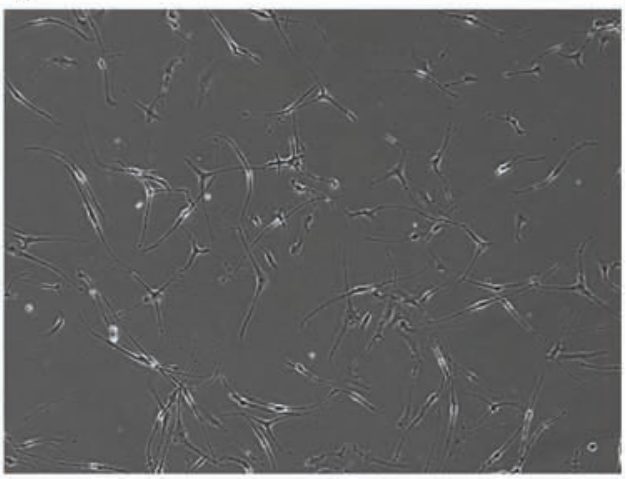

E

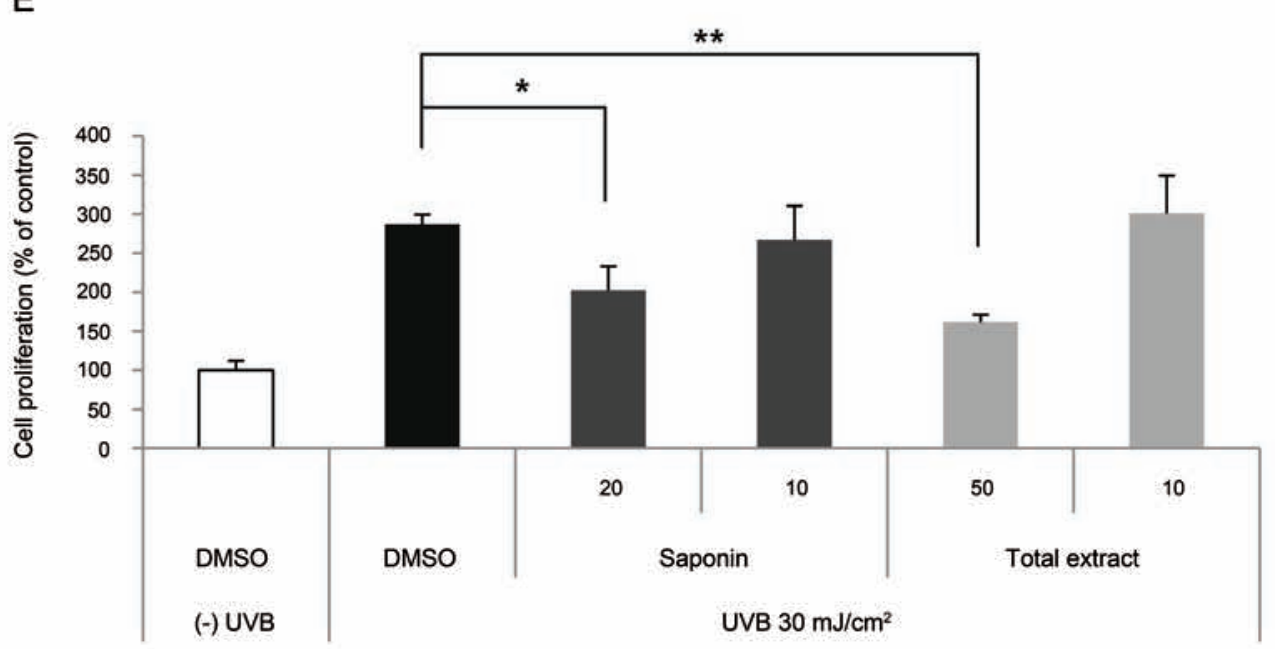

Concentration (ppm)

Fig. 5. Effect of Korean Red Ginseng (KRG) on melan-A melanocyte proliferation induced by conditioned media from UV-irradiated SP-1 keratinocytes. Before UV irradiation, SP-1 keratinocyte cells were treated with serum free Eagle's Minimum Essential Medium (EMEM) containing total extract or saponin of KRG (SKRG) (10, 20, and $50 \mathrm{ppm})$. After $24 \mathrm{~h}$, SP-1 keratinocytes were irradiated with UVB at a dose of $30 \mathrm{~mJ} / \mathrm{cm}^{2}$. Immediately, the cells were treated with $2 \%$ newborn calf serum EMEM containing total extract or SKRG (10,20, and $50 \mathrm{ppm})$. (A) Control, (B) UVB (30 mJ/cm²), (C) SKRG (20 ppm), (D) total extract (50 ppm), and (E) cell proliferation assay. Cells were observed under a phase-contrast microscope (Olympus CKX41; Olympus Optical, Tokyo, Japan) and images were photographed using a DMCe camera (INS Industry, Seoul, Korea) and the included DMC advanced software $(\times 100)$. Data are shown as average \pm SEM. DMSO, dimethyl sulfoxide. ${ }^{\star} p<0.05,{ }^{\star \star} p<0.01$, compared with the control.

cells/dish). After $24 \mathrm{~h}$, the cells were washed with DPBS and replenished with serum-free EMEM containing total extract and saponin of KRG. After starvation for $24 \mathrm{~h}$, SP-1 keratinocytes were washed with DPBS and exposed 


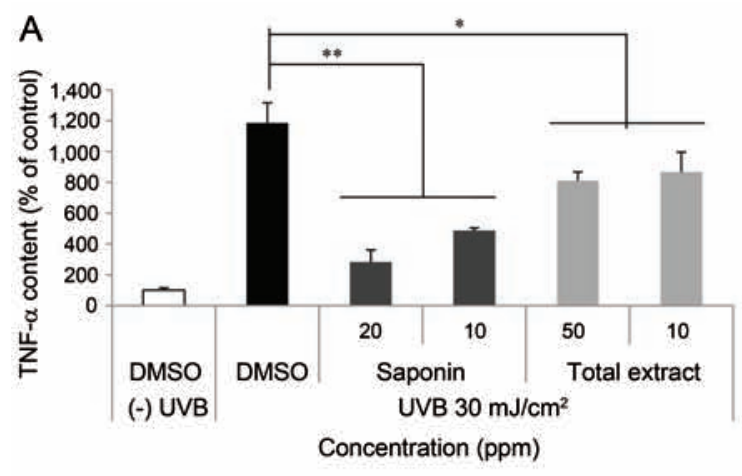

B

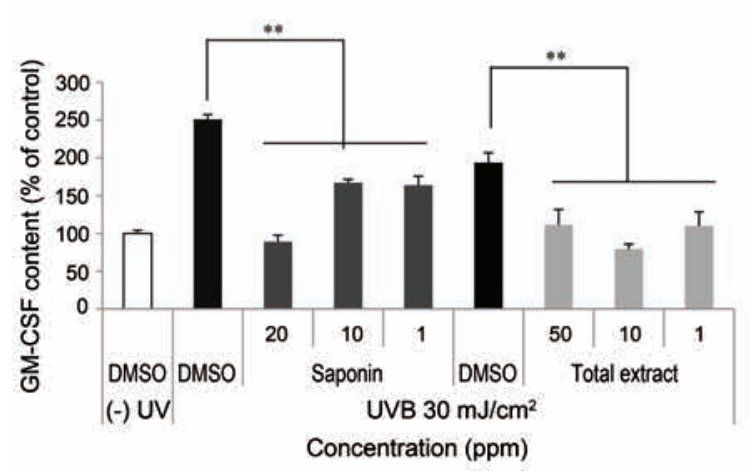

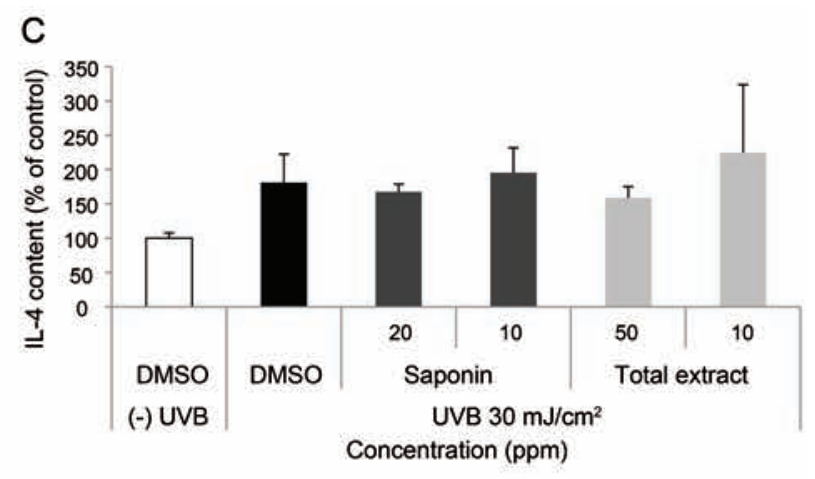

D

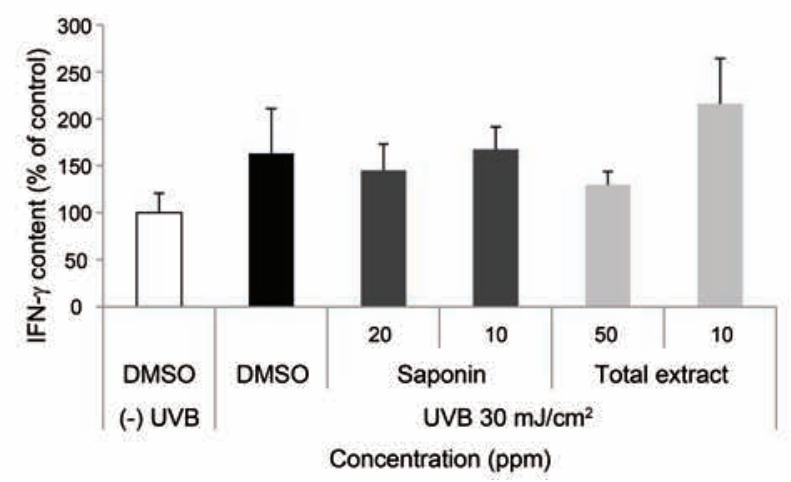

Fig. 6. Effect of Korean Red Ginseng (KRG) on the expression of cytokines in UV-irradiated SP-1 keratinocytes. Before UV irradiation, SP-1 keratinocyte were treated with serum free Eagle's Minimum Essential Medium (EMEM) containing total extract or saponin of KRG (SKRG) (10, 20 , and $50 \mathrm{ppm}$ ). After $24 \mathrm{~h}, \mathrm{SP}-1$ keratinocytes were irradiated with UVB at a dose of $30 \mathrm{~mJ} / \mathrm{cm}^{2}$. Immediately, the cells were treated with $2 \%$ newborn calf serum EMEM containing total extract or SKRG (10, 20, and 50 ppm). After $24 \mathrm{~h}$, the conditioned media was measured by enzymelinked immunosorbent assay as described in the Materials and Methods section. (A) Tumor necrosis factor (TNF)- $\alpha$, (B) granulocyte macrophage colony-stimulating factor (GM-CSF), (C) interleukin (IL)-4, and (D) interferon (IFN)- $\mathrm{Y}$. Data are shown as average $\pm S E M$, DMSO, dimethyl sulfoxide. ${ }^{*} p<0.05,{ }^{* \star} p<0.01$, compared with the control.

to UV radiation by a UV irradiation system. After irradiation, the cells were replaced with 2\% NBCS EMEM containing total extract and saponin of KRG. After $24 \mathrm{~h}$, the conditioned media was used to treat melan-A melanocytes for 24 to $72 \mathrm{~h}$.

The cell density was markedly increased in UVB irradiated SP-1 keratinocyte conditioned media treated melan-A cells (Fig. 5B), compared with the non-irradiated control (Fig. 5A) at 72 h. SP-1 conditioned media treated with SKRG (Fig. 5C) or KRGE (Fig. 5D) reduced melanA melanocyte densities compared with the UVB irradiated SP-1 keratinocyte conditioned media treated melan-A cells. Treatment of melan-A melanocytes with conditioned media from UVB-irradiated SP-1 keratinocytes increased cell proliferation by three-fold. SP-1 conditioned media treated with KRGE or SKRG inhibited melan-A melanocyte proliferation by about $50 \%$ at 50 ppm KRGE and $40 \%$ at 20 ppm SKRG, respectively (Fig. 5E).

\section{Effect of Korean Red Ginseng on the expression of cytokines in UV-irradiated SP-1 keratinocytes}

UVB exposure stimulates the production of proinflammatory cytokines such as interferon (IFN)- $\gamma$, IL6 , and TNF- $\alpha$, which are implicated in the progression of pigmentation [52]. To elucidate the effect of KRG on UVB-induced cytokine expression in SP-1 keratinocytes, we measured the production of cytokines (IFN- $\gamma$, IL-4, TNF- $\alpha$, and GM-CSF) using an ELISA kit (eBioscience). UVB irradiation increased cytokine expression (IFN- $\gamma$, IL-4, TNF- $\alpha$, and GM-CSF) in SP-1 keratinocytes compared with the non-irradiated control. SKRG decreased expression of TNF- $\alpha$ by $75 \%$ compared with the untreated irradiated control (Fig. 6A). In addition, saponin and total KRGE decreased expression of GM-CSF by $60 \%$ compared with the untreated irradiated control (Fig. 6B). However, the expression of IL-4 (Fig. 6C) and IFN- $\gamma$ (Fig. 6D) was not changed. 
A

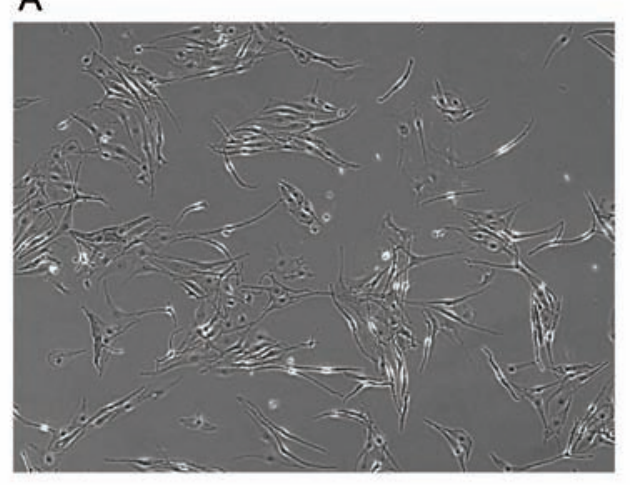

B

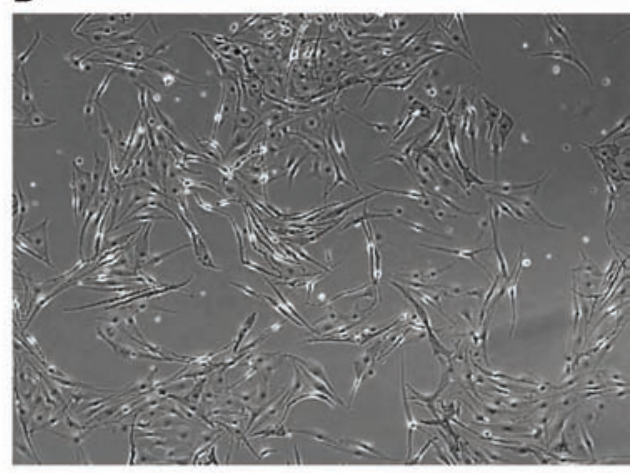

C

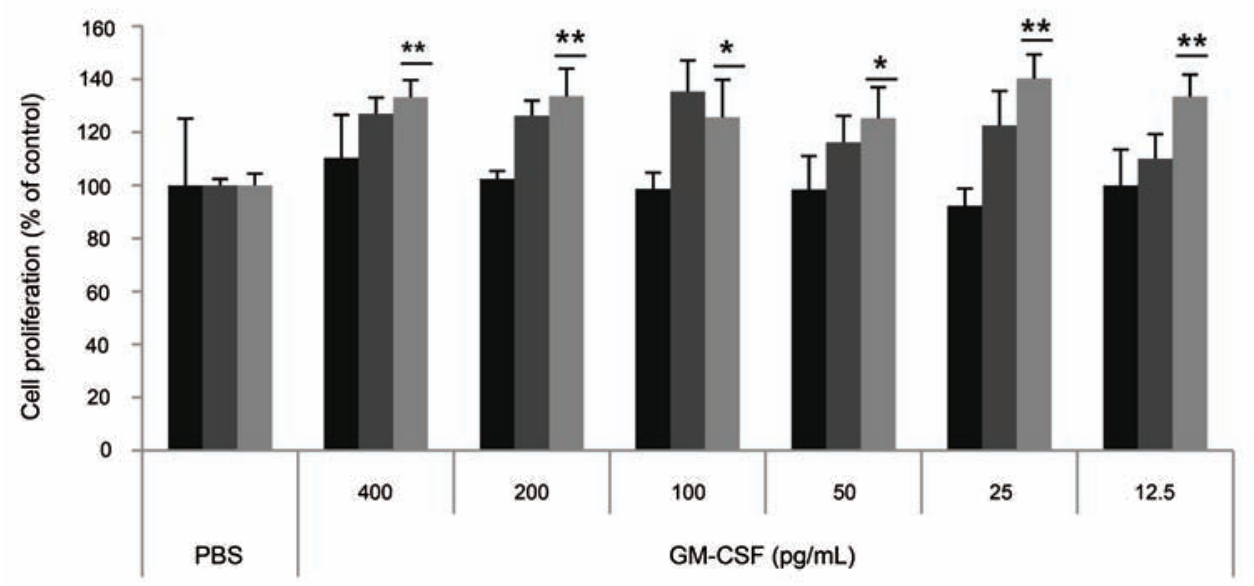

Fig. 7. Effect of granulocyte macrophage colony-stimulating factor (GM-CSF) on melan-A melanocyte proliferation. (A) Melan-A melanocytes $\left(1 \times 10^{4}\right.$ cells/well $)$ were cultured in 24 well plates. After incubation with $400,200,100,50,25$, or $12.5 \mathrm{pg} / \mathrm{mL} \mathrm{GM}-\mathrm{CSF}$ for 24,48 , and $72 \mathrm{~h}$, cell proliferation was measured as described in the Materials and Methods section section. (A) Control, (B) GM-CSF (25 pg/mL), and (C) cell proliferation assay. Cells were observed under a phase-contrast microscope (Olympus CKX41, Olympus Optical, Tokyo, Japan) and images were photographed using a DMCe camera (INS Industry, Seoul, Korea) and the included DMC advanced software $(\times 100)$. Data are shown as average \pm SEM. PBS, phosphate buffered saline. ${ }^{*} p<0.05$, ${ }^{* *} p<0.01$, compared with the control.

Effect of granulocyte macrophage colony-stimulating factor on melan-A melanocyte proliferation

To determine whether GM-CSF increases melan-A melanocyte proliferation, cell proliferation was measured after treatment with GM-CSF (12.5-400 pg/mL) to melan-A melanocyte directly. The cell density was increased in $25 \mathrm{pg} / \mathrm{mL}$ GM-CSF treated melan-A cells (Fig. 7B) compared with control cells (Fig. 7A) at 72 h, GMCSF treatment increased melan-A melanocyte proliferation by about $40 \%$ at $25 \mathrm{pg} / \mathrm{mL}$ (Fig. $7 \mathrm{C}$ ).

Effect of granulocyte macrophage colony-stimulating factor from UVB-irradiated SP-1 keratinocytes on melanocyte proliferation

We determined whether GM-CSF from UVB-irradiat- ed SP-1 keratinocytes involved in melan-A melanocyte proliferation by pre-treatment with neutralizing antiGM-CSF antibodies. Conditioned media from UVBirradiated SP-1 keratinocytes increased melan-A melanocyte proliferation by about two-fold compared with the non-irradiated control (Fig. 8A, B). When antibodies (0.1 $\mu \mathrm{g} / \mu \mathrm{L}$ ) against GM-CSF were added, UVB-irradiated SP-1 keratinocytes conditioned media inhibited melan-A melanocyte proliferation (Fig. 8C) compared with UVBirradiated control (Fig. 8B). Anti-GM-CSF treatment decreased melan-A melanocyte proliferation by about $50 \%$ at $0.1 \mu \mathrm{g} / \mu \mathrm{L}$ (Fig. 8D). GM-CSF-specific antibodies partially abolished the proliferating effects of UVB irradiated SP-1 keratinocyte conditioned media on melan-A melanocytes. 
A

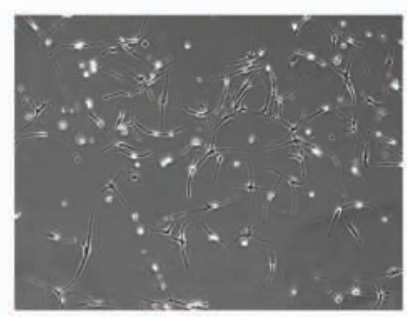

B

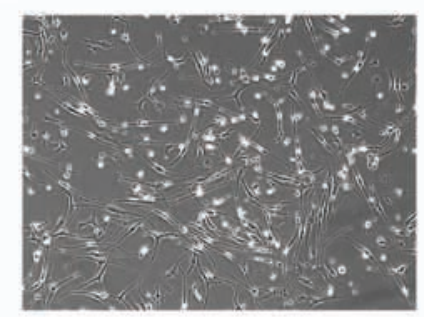

C

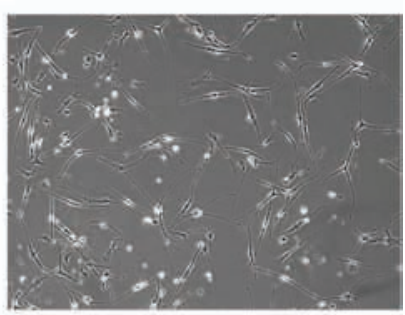

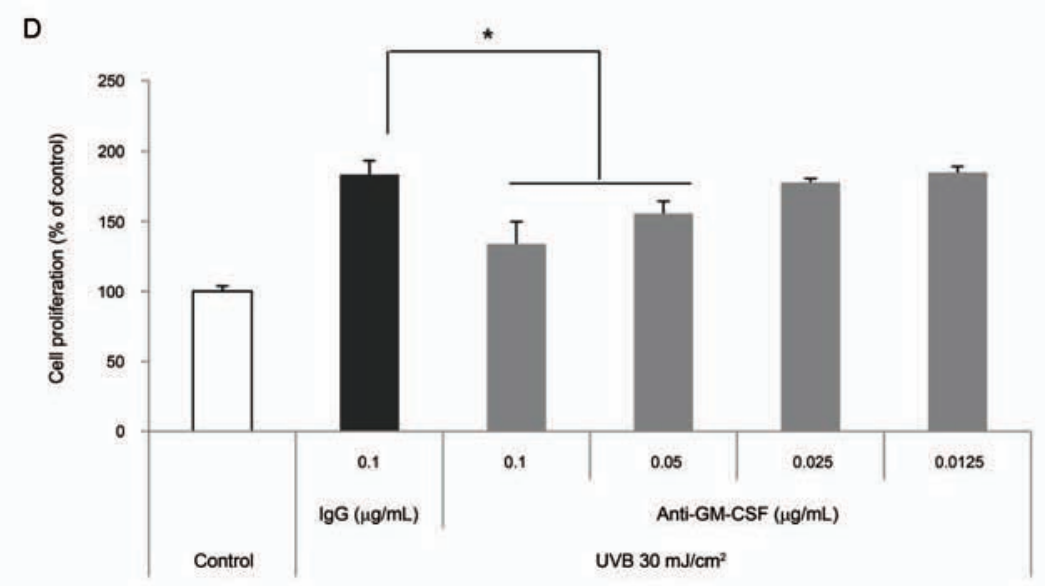

Fig. 8. Effect of conditioned media from UVB-irradiated SP-1 keratinocytes treated with anti-granulocyte macrophage colony-stimulating factor (GM-CSF) on melanocyte proliferation. SP-1 keratinocytes were irradiated with UVB at a dose of $30 \mathrm{~mJ} / \mathrm{cm}^{2}$. Immediately, the cells were treated with r-lgG or anti-GM-CSF. After $24 \mathrm{~h}$, the conditioned media was used to treat melan-A melanocytes seeded in 24 well plates $\left(1 \times 10^{4}\right.$ cells/well) for $3 \mathrm{~d}$. (A) Control, (B) r-lgG $(0.1 \mu \mathrm{g} / \mu \mathrm{L})$, (C) anti-GM-CSF $(0.1 \mu \mathrm{g} / \mu \mathrm{L})$, and (D) cell proliferation assay. Cells were observed under a phase-contrast microscope (Olympus CKX41, Olympus Optical, Tokyo, Japan) and images were photographed using a DMCe camera (INS Industry, Seoul, Korea) and the included DMC advanced software $(\times 100)$. Data are shown as average \pm SEM. ${ }^{*} p<0.05$, compared with the control.

\section{DISCUSSION}

KRG has a wide range of pharmacological and physiological actions, which include memory enhancing activities, antihypertensive, antitumor, antistress, antidiabetic, potentiation of erectile response, aphrodisiac, atopic dermatitis, anti-aging, anti-oxidant, and anti-inflammatory activities [8-18].

Although KRG has been used as an effective agent with protective and curable roles in a variety of diseases, it has not been studied for a protective role against UVinduced pigmentation. We examined the effects of KRG on the regulation of melanocyte proliferation and key molecules involved in UV-induced pigmentation.

Hyperpigmentation is characterized by an abnormal increase of melanin in the skin [22,23]. Recently, many efforts have focused on understanding the mechanical insights of melanogenesis to develop new therapeutic agents against skin pigmentation abnormalities. Tyrosinase is a key enzyme in melanogenesis that plays a regulatory role in the production of melanin [47]. Total extract and SKRG did not inhibit tyrosinase activity (Fig. 1). SKRG slightly inhibited melanin synthesis in melanA melanocytes. However, KRGE did not inhibit melanin synthesis (Fig. 2). These results suggest that KRG weakly inhibits tyrosinase activity and melanin synthesis.

We showed that conditioned media from UV-irradiated SP-1 keratinocytes increased melan-A melanocyte proliferation. Specifically, conditioned media from UVB-irradiated SP-1 keratinocytes increased melan-A melanocyte proliferation about two-fold compared with conditioned media from non-irradiated SP-1 keratinocytes (Fig. 4). On the other hand, conditioned media from UVB-irradiated SP-1 keratinocytes treated with KRGE decreased melan-A melanocyte proliferation by 50\% (Fig. 5).

Paracrine regulation of melanogenesis by keratinocyte-derived factors has been reported [39-46]. Some cytokines such as GM-CSF, IL-4, IFN- $\gamma$, and TNF- $\alpha$ are known to be elevated in keratinocytes exposed to UVB and are associated with apoptotic cell death, inflammation, and immunosuppression [53]. We found that UVB irradiation $\left(30 \mathrm{~mJ} / \mathrm{cm}^{2}\right)$ significantly elevated GM-CSF, 
IL-4, IFN- $\gamma$, and TNF- $\alpha$ in SP-1 keratinocytes. The expression of GM-CSF and TNF- $\alpha$ was suppressed by KRG in a dose-dependent manner (Fig. 6).

GM-CSF [54] induces myeloid progenitor cells from bone marrow to form colonies containing granulocytes and macrophages in semisolid media. GM-CSF also acts on mature macrophages, eosinophils, and neutrophils to stimulate various functional activities [55]. GM-CSF is an acidic glycoprotein (human=18-22 $\mathrm{kDa}$ [55]; mouse=23 $\mathrm{kDa}[56]$ ), which binds to high affinity receptors on GMCSF-sensitive cells. In addition to hematopoietic cells, GM-CSF stimulates migration and proliferation of human endothelial cells [57]. Mammalian keratinocytes are capable of producing GM-CSF following external stimulation, and GM-CSF is involved in regulating the proliferation of keratinocytes in an autocrine manner [58]. GM-CSF is also involved in regulating the proliferation and differentiation of epidermal melanocytes [46]. In this study, we showed that conditioned medium from UV-irradiated SP-1 keratinocytes increased melanocyte proliferation. However, conditioned media from UV-irradiated SP-1 keratinocytes treated with KRGE decreased melanA melanocyte proliferation. GM-CSF was produced and released from UV-irradiated SP-1 keratinocytes. The proliferation of melan-A melanocytes increased significantly by GM-CSF treatment (Fig. 7). In addition, the effect of SP-1 keratinocyte conditioned media on melanA melanocyte proliferation was nulled by anti-GM-CSF treatment (Fig. 8). The expression of GM-CSF in UVirradiated SP-1 keratinocytes decreased due to KRGE treatment. Thus, these results suggest that KRG inhibited melan-A melanocyte proliferation by decreasing expression of GM-CSF from UV-irradiated SP-1 keratinocytes and the inhibitory effect of KRG on GM-CSF is mainly from saponin in KRGE.

In conclusion, our results provide insights into the use of KRG for hyperpigmentory problems and skin whitening. Further studies are required to elucidate the inhibitory mechanism of KRG on GM-CSF expression in UVirradiated keratinocytes.

\section{ACKNOWLEDGEMENTS}

This work was supported by the 2011 grant from the Korean Society of Ginseng.

\section{REFERENCES}

1. Attele AS, Wu JA, Yuan CS. Ginseng pharmacology: multiple constituents and multiple actions. Biochem Phar- macol 1999;58:1685-1693.

2. Tachikawa E, Kudo K, Harada K, Kashimoto T, Miyate Y, Kakizaki A, Takahashi E. Effects of ginseng saponins on responses induced by various receptor stimuli. Eur J Pharmacol 1999;369:23-32.

3. Yin H, Park SA, Park SJ, Han SK. Korean red ginseng extract activates non-NMDA glutamate and GABAA receptors on the substantia gelatinosa neurons of the trigeminal subnucleus caudalis in mice. J Ginseng Res 2011;35:219225.

4. Yun TK. Brief introduction of Panax ginseng C.A. Meyer. J Korean Med Sci 2001;16 Suppl:S3-S5.

5. Lee KG, Son SW. Efficacy of Korean red ginseng in the treatment of atopic dermatitis. J Ginseng Res 2011; 35:149-154.

6. Yang H, Lee SE, Jeong SI, Park CS, Jin YH, Park YS. Up-regulation of heme oxygenase-1 by Korean red ginseng water extract as a cytoprotective effect in human endothelial cells. J Ginseng Res 2011;35:352-359.

7. Xiang YZ, Shang HC, Gao XM, Zhang BL. A comparison of the ancient use of ginseng in traditional Chinese medicine with modern pharmacological experiments and clinical trials. Phytother Res 2008;22:851-858.

8. Jin SH, Park JK, Nam KY, Park SN, Jung NP. Korean red ginseng saponins with low ratios of protopanaxadiol and protopanaxatriol saponin improve scopolamine-induced learning disability and spatial working memory in mice. J Ethnopharmacol 1999;66:123-129.

9. Jeon BH, Kim CS, Kim HS, Park JB, Nam KY, Chang SJ. Effect of Korean red ginseng on blood pressure and nitric oxide production. Acta Pharmacol Sin 2000;21:10951100.

10. Surh YJ, Ferguson LR. Dietary and medicinal antimutagens and anticarcinogens: molecular mechanisms and chemopreventive potential--highlights of a symposium. Mutat Res 2003;523-524:1-8.

11. Kaneko H, Nakanishi K. Proof of the mysterious efficacy of ginseng: basic and clinical trials: clinical effects of medical ginseng, Korean red ginseng: specifically, its anti-stress action for prevention of disease. J Pharmacol Sci 2004;95:158-162.

12. Vuksan V, Sung MK, Sievenpiper JL, Stavro PM, Jenkins AL, Di Buono M, Lee KS, Leiter LA, Nam KY, Arnason JT et al. Korean red ginseng (Panax ginseng) improves glucose and insulin regulation in well-controlled, type 2 diabetes: results of a randomized, double-blind, placebocontrolled study of efficacy and safety. Nutr Metab Cardiovasc Dis 2008;18:46-56.

13. Choi HK, Seong DH, Rha KH. Clinical efficacy of Korean red ginseng for erectile dysfunction. Int J Impot Res 
1995;7:181-186.

14. De Andrade E, de Mesquita AA, Claro Jde A, de Andrade PM, Ortiz V, Paranhos M, Srougi M. Study of the efficacy of Korean red ginseng in the treatment of erectile dysfunction. Asian J Androl 2007;9:241-244.

15. Cho E, Cho SH. Effects of Korean red ginseng extract on the prevention of atopic dermatitis and its mechanism on early lesions in a murine model. J Ethnopharmacol 2013;145:294-302.

16. Lee HS, Kim MR, Park Y, Park HJ, Chang UJ, Kim SY, Suh HJ. Fermenting red ginseng enhances its safety and efficacy as a novel skin care anti-aging ingredient: in vitro and animal study. J Med Food 2012;15:1015-1023.

17. Han BH, Park MH, Han YN. Studies on the anti-oxidant components of Korean ginseng. In: Korea Ginseng Research Institute. Proceedings of 2nd International Ginseng Symposium; Seoul, Korea. Seoul: Korea Ginseng Research Institute, 1978. p.13-17.

18. Jung HL, Kwak HE, Kim SS, Kim YC, Lee CD, Byurn HK, Kang HY. Effects of Panax ginseng supplementation on muscle damage and inflammation after uphill treadmill running in humans. Am J Chin Med 2011;39:441-450.

19. Sugai T. Clinical effects of arbutin in patients with cholasma. Skin Res 1992;34:522.

20. Mishima Y, Imokawa G. Selective aberration and pigment loss in melanosomes of malignant melanoma cells in vitro by glycosylation inhibitors: premelanosomes as glycoprotein. J Invest Dermatol 1983;81:106-114.

21. Imokawa G, Mishima Y. Loss of melanogenic properties in tyrosinases induced by glucosylation inhibitors within malignant melanoma cells. Cancer Res 1982;42:19942002.

22. Hearing VJ. Biochemical control of melanogenesis and melanosomal organization. J Investig Dermatol Symp Proc 1999;4:24-28.

23. Imokawa G, Kawai M, Mishima Y, Motegi I. Differential analysis of experimental hypermelanosis induced by UVB, PUVA, and allergic contact dermatitis using a brownish guinea pig model. Arch Dermatol Res 1986; 278:352-362.

24. Abdel-Malek Z, Swope V, Smalara D, Babcock G, Dawes S, Nordlund J. Analysis of the UV-induced melanogenesis and growth arrest of human melanocytes. Pigment Cell Res 1994;7:326-332.

25. Rosdahl IK, Szabo G. Mitotic activity of epidermal melanocytes in UV-irradiated mouse skin. J Invest Dermatol 1978;70:143-148.

26. Dissanayake NS, Greenoak GE, Mason RS. Effects of ultraviolet irradiation on human skin-derived epidermal cells in vitro. J Cell Physiol 1993;157:119-127.
27. Gilchrest BA, Park HY, Eller MS, Yaar M. Mechanisms of ultraviolet light-induced pigmentation. Photochem Photobiol 1996;63:1-10.

28. Yamaguchi Y, Hearing VJ. Melanocyte distribution and function in human skin: effects of UV radiation. In: Hearing VJ, Leong SP, eds. Melanocytes to malignant melanoma: the progression to malignancy. Totowa: Humana Press, 2006. p.101-115.

29. Matsumura Y, Ananthaswamy HN. Toxic effects of ultraviolet radiation on the skin. Toxicol Appl Pharmacol 2004;195:298-308.

30. Gloster HM Jr, Brodland DG. The epidemiology of skin cancer. Dermatol Surg 1996;22:217-226.

31. Ullrich SE. Mechanisms underlying UV-induced immune suppression. Mutat Res 2005;571:185-205.

32. Cox NH, Diffey BL, Farr PM. The relationship between chronological age and the erythemal response to ultraviolet B radiation. Br J Dermatol 1992;126:315-319.

33. Gilchrest BA. A review of skin ageing and its medical therapy. Br J Dermatol 1996;135:867-875.

34. Furuya R, Akiu S, Ideta R, Naganuma M, Fukuda M, Hirobe $\mathrm{T}$. Changes in the proliferative activity of epidermal melanocytes in serum-free primary culture during the development of ultraviolet radiation B-induced pigmented spots in hairless mice. Pigment Cell Res 2002;15:348356.

35. Furuya R, Yoshida Y, Moro O, Tsunenaga M, Aoki H, Kishimoto J, Ifuku O, Hirobe T. Immunohistochemical survey of the distribution of epidermal melanoblasts and melanocytes during the development of UVB-induced pigmented spots. J Dermatol Sci 2009;55:99-107.

36. Hirobe T. Role of keratinocyte-derived factors involved in regulating the proliferation and differentiation of mammalian epidermal melanocytes. Pigment Cell Res 2005;18:212.

37. Imokawa G. Autocrine and paracrine regulation of melanocytes in human skin and in pigmentary disorders. Pigment Cell Res 2004;17:96-110.

38. Naganumaa M, Yagi E, Fukuda M. Delayed induction of pigmented spots on UVB-irradiated hairless mice. J Dermatol Sci 2001;25:29-35.

39. Kupper TS, Chua AO, Flood P, McGuire J, Gubler U. Interleukin 1 gene expression in cultured human keratinocytes is augmented by ultraviolet irradiation. J Clin Invest 1987;80:430-436.

40. Enk CD, Sredni D, Blauvelt A, Katz SI. Induction of IL-10 gene expression in human keratinocytes by UVB exposure in vivo and in vitro. J Immunol 1995;154:48514856.

41. Kock A, Schwarz T, Kirnbauer R, Urbanski A, Perry P, 
Ansel JC, Luger TA. Human keratinocytes are a source for tumor necrosis factor alpha: evidence for synthesis and release upon stimulation with endotoxin or ultraviolet light. J Exp Med 1990;172:1609-1614.

42. Halaban R, Langdon R, Birchall N, Cuono C, Baird A, Scott G, Moellmann G, McGuire J. Basic fibroblast growth factor from human keratinocytes is a natural mitogen for melanocytes. J Cell Biol 1988;107:1611-1619.

43. Imokawa G, Kobayasi T, Miyagishi M. Intracellular signaling mechanisms leading to synergistic effects of endothelin-1 and stem cell factor on proliferation of cultured human melanocytes. Cross-talk via trans-activation of the tyrosine kinase c-kit receptor. J Biol Chem 2000; 275:33321-33328.

44. Funasaka Y, Chakraborty AK, Hayashi Y, Komoto M, Ohashi A, Nagahama M, Inoue Y, Pawelek J, Ichihashi M. Modulation of melanocyte-stimulating hormone receptor expression on normal human melanocytes: evidence for a regulatory role of ultraviolet $B$, interleukin-1alpha, interleukin-1beta, endothelin-1 and tumour necrosis factoralpha. Br J Dermatol 1998;139:216-224.

45. Hachiya A, Kobayashi A, Yoshida Y, Kitahara T, Takema Y, Imokawa G. Biphasic expression of two paracrine melanogenic cytokines, stem cell factor and endothelin-1, in ultraviolet B-induced human melanogenesis. Am J Pathol 2004;165:2099-2109.

46. Hirobe T, Furuya R, Hara E, Horii I, Tsunenaga M, Ifuku O. Granulocyte-macrophage colony-stimulating factor (GM-CSF) controls the proliferation and differentiation of mouse epidermal melanocytes from pigmented spots induced by ultraviolet radiation B. Pigment Cell Res 2004;17:230-240.

47. Marshall CJ. Specificity of receptor tyrosine kinase signaling: transient versus sustained extracellular signalregulated kinase activation. Cell 1995;80:179-185.

48. Eimpunth S, Wanitphadeedecha R, Manuskiatti W. A focused review on acne-induced and aesthetic procedurerelated postinflammatory hyperpigmentation in Asians. $\mathrm{J}$ Eur Acad Dermatol Venereol 2013;27 Suppl 1:7-18.

49. Bennett DC, Cooper PJ, Hart IR. A line of non-tumorigenic mouse melanocytes, syngeneic with the B16 melanoma and requiring a tumour promoter for growth. Int $\mathrm{J}$ Cancer 1987;39:414-418.
50. Strickland JE, Greenhalgh DA, Koceva-Chyla A, Hennings H, Restrepo C, Balaschak M, Yuspa SH. Development of murine epidermal cell lines which contain an activated rasHa oncogene and form papillomas in skin grafts on athymic nude mouse hosts. Cancer Res 1988;48:165169.

51. Cabanes J, Chazarra S, Garcia-Carmona F. Kojic acid, a cosmetic skin whitening agent, is a slow-binding inhibitor of catecholase activity of tyrosinase. J Pharm Pharmacol 1994;46:982-985.

52. Marini A, Farwick M, Grether-Beck S, Brenden H, Felsner I, Jaenicke T, Weber M, Schild J, Maczkiewitz U, Kohler $\mathrm{T}$ et al. Modulation of skin pigmentation by the tetrapeptide PKEK: in vitro and in vivo evidence for skin whitening effects. Exp Dermatol 2012;21:140-146.

53. Brouxhon S, Konger RL, VanBuskirk J, Sheu TJ, Ryan J, Erdle B, Almudevar A, Breyer RM, Scott G, Pentland AP. Deletion of prostaglandin E2 EP2 receptor protects against ultraviolet-induced carcinogenesis, but increases tumor aggressiveness. J Invest Dermatol 2007;127:439446.

54. Gasson JC, Weisbart RH, Kaufman SE, Clark SC, Hewick RM, Wong GG, Golde DW. Purified human granulocytemacrophage colony-stimulating factor: direct action on neutrophils. Science 1984;226:1339-1342.

55. Morstyn G, Burgess AW. Hemopoietic growth factors: a review. Cancer Res 1988;48:5624-5637.

56. Wong GG, Witek JS, Temple PA, Wilkens KM, Leary AC, Luxenberg DP, Jones SS, Brown EL, Kay RM, Orr EC et al. Human GM-CSF: molecular cloning of the complementary DNA and purification of the natural and recombinant proteins. Science 1985;228:810-815.

57. Bussolino F, Wang JM, Defilippi P, Turrini F, Sanavio F, Edgell CJ, Aglietta M, Arese P, Mantovani A. Granulocyte- and granulocyte-macrophage-colony stimulating factors induce human endothelial cells to migrate and proliferate. Nature 1989;337:471-473.

58. Mann A, Breuhahn K, Schirmacher P, Blessing M. Keratinocyte-derived granulocyte-macrophage colony stimulating factor accelerates wound healing: stimulation of keratinocyte proliferation, granulation tissue formation, and vascularization. J Invest Dermatol 2001;117:13821390. 